В таблице 1 представлены данные по выходу загрязняющих веществ и сажи, улавливаемых на фильтреи золы при сжигании угольнойшихты в соотношении 1:1.

Таблиияа 1

Выходы летучих веществ, сажи и золы при сжигании угольной шихты (1:1)

\begin{tabular}{|c|c|c|c|c|}
\hline Наименование & $\begin{array}{c}\text { Масса } \\
\text { летучих } \\
\text { веществ и } \\
\text { сажи, г }\end{array}$ & $\begin{array}{c}\text { Масса } \\
\text { золы, г }\end{array}$ & $\begin{array}{c}\text { Выход } \\
\text { летучих } \\
\text { веществ и } \\
\text { сажи, \% }\end{array}$ & $\begin{array}{c}\text { Время } \\
\text { сграния, } \\
\text { мин }\end{array}$ \\
\hline Каа-хемский: элегестский & 0,014 & 4,838 & 0,14 & 15 \\
\hline Каа-хемский: балахтинский & 0,004 & 2,625 & 0,04 & 13 \\
\hline $\begin{array}{c}\text { Каа-хемский: межегейский } \\
\text { окисленный }\end{array}$ & 0,026 & 3,382 & 0,26 & 12 \\
\hline
\end{tabular}

Наибольшим выходом загрязняющих летучих веществ и сажипри сжигании в печи с фильтром для улавливания характеризовался каа-хемский уголь. Наименьший выход загрязняющих веществ, улавливаемых на фильтре,был характерен для межегейского окисленного угля, масса летучих веществ и сажи составила 0,002 г.

Наименьший выход золы составил 2,466 г при сжигании шихты изкаа-хемского и балахтинского углей в соотношении 2:1, наибольший выход золы составил 4,835 г при сжигании шихты из каа-хемского и элегестского углей в соотношении 1:1.

На основании исследований получены новые данные показывающие экологические преимущества сжигания смесей углей с некондиционными углями. Данные о подобранных составах угольной шихты необходимы для разработки установки с бесконтактным нагревом угля.

$$
* * *
$$

1. Куликова М.П. Исследование физико-химических свойств улуг-хемских углей /Энергетик.-2014.-№ 8.-C.29-33.

2. Куликова М.П. Газоносность угольных пластов Улуг - Хемского бассейна./ Вестник ТувГУ. Естественные и сельскохозяйственные науки. Выпуск 29. 2016. С. 138-144.

3. К.К. Чульдум, М.П. Куликова. Обоснование принципиальной схемы установки для термохимической переработки углей./ Вестник ТувГУ, №2, 2017.-с.106-111.

\title{
Сагар A.A. \\ Химический анализ поверхностных вод, отобранных в пределах межегейского угольного месторождения
}

Тувинский государственный университет

(Россия, Кьзыьл)

doi:10.18411/spc-22-04-2018-03

idsp: 000001:spc-22-04-2018-03

В Туве основные запасы каменных углей сосредоточены в Улуг-Хемском угольном бассейне, общие ресурсы коксующихся углей оцениваются в 937 млн. тонн. Общая площадь бассейна порядка 2700 км2, в его пределах оценены 4 месторождения: Каа-Хемское, Межегейское, Элегесткое и Эрбекское [2].

С 1 сентября 2013 года ООО «УК Межегейуголь», принадлежащее «Евраз Холдинг», планирует вложить в разработку Межегейского месторождения каменного угля в Туве от 40 до 50 миллиардов рублей до 2030 года, сообщает республиканское министерство экономики. Проект 6 предусматривает строительство комплекса промышленных предприятий, которые должны обеспечить работу угольной шахты, получение конечной товарной продукции - концентрата и транспортировку. По информации Минэкономики, в настоящее время проводятся проектно-сметные работы [2]. 
Балансовые запасы категории $\mathrm{A}+\mathrm{B}+\mathrm{C} 1$ по Межегейскому месторождению составляют 213,5 миллиона тонн, забалансовые - 53,4 миллиона тонн. Межегейское месторождение расположено в юго-западной части Кызылско-Эрбекской мульды на территории Тандинского кожууна, центром которого является пос. Бай-Хаак [4].

Растительность - степная, в долинах рек встречаются рощи тополя, черемухи и различные виды кустарниковых, в основном караганника. Климат района месторождения типичный резко континентальный, как и о всем Улуг - Хемском угольном бассейне, характеризующийся теми же показателями.Гидрографический район месторождения принадлежит к бассейну р. Верхний Енисей (Улуг-Хем). Вблизи юго-восточной границы месторождения находятся соленые озера Хадын, Дус-Холь и Кач-Холь, рапа которых обладает целебными свойствами. Источников технического и питьевого водоснабжения может служить вода р. Элегест [3]. Экономически район сравнительно освоен. Месторождение находиться в 35-40 км к югу-западу от Кызыла столицы республики. От г. Кызыла до месторождения можно доехать по шоссе с асфальтовым покрытием. [5].

В экономическом развитии любого региона инвестиционная деятельность является важным аспектом для решения многих социально-экономических проблем. Вблизи расположены несколько поселков, жители которых заняты преимущественно в сельском хозяйстве.

В экономическом развитии любого региона инвестиционная деятельность является важным аспектом для решения многих социально- экономических проблем.

Вскрытие и эксплуатация угольных месторождений связаны с непременной откачкой воды, попадающей в горные выработки.На некоторых водообильных месторождениях для создания благоприятных условий ведения горных работ производят предварительное осушение полей полезных ископаемых, откачиваемая на угледобывающих предприятиях вода является попутно забираемой, она относится к сточной, так как подвергается загрязнению. Попутно забираемые воды являются природными. Таким образом, при разработке угольных месторождений необходимо проводить мониторинг состояния природных вод.

Целью работы явилось определение физико-химических показателей и изучение химического состава анализируемых проб воды.

Отбор проб воды в пределах Межегейского угольного месторождения производился согласно ГОСТ 17.1.5.04 - 81 в сентябре 2016 года.

Изучали качество воды рек Межегей, Элегест, Дурген, Шанган и шахтные воды из промышленных стоков в пределах Межегейского угольного месторождения.

Таким образом, в данной работе мы отслеживаем сезонность исследований водного бассейна в пределах изучаемой территории.

Для химического анализа использовали следующие методы:

1. Фотометрический метод анализа - определение мутности, цветности, содержание сульфат-ионов, нитрат-ионов, общее содержание ионов железа в анализируемых водах;

2. Титриметрический метод анализа - определение содержания ионов кальция, магния, хлорид-ионов, гидрокарбонат-ионов и определение общей жесткости в исследуемых водах; проб[1].

3. Потенциометрический метод анализа для определения рН изучаемых водных

По результатам выполненных исследований можно сделать следующие выводы:

1. Химический анализ поверхностных вод, находящихся в районе проектируемого Межегейского угольного месторождения, начинается с установления их качества, так как показатели качества воды сильно влияют на органолептические свойства воды. 
2. Температура проб воды соответствует сезону, значения $\mathrm{pH}$ тоже. В шкале цветности, пробы 1, 2, 3 и 6 имеют очень малую цветность, они практически бесцветны. Пробы 4,5 и 7 имеют желтоватый оттенок, поэтому у них большая цветность.

3. Исследуемые воды имели щелочную реакцию среды. Содержание гидрокарбонат- ионов в воде достигало 131,15 мг/дм3, а хлорид- и сульфат- ионов 40,69 мг/дм3 и 30,0 мг/дм3. Содержание нитрат- ионов было незначительным и достигало 16 мг/дм3. Концентрация ионов магния варьировала в пределах 41,31-25,76 мг/дм3, кальция - 24,25-16,03 мг/дм3. Содержание катионов и анионов в исследуемых пробах воды не превышало ПДК.

$$
* * *
$$

1. Васильев В.П. Аналитическая химия ч.2. Физико-химические методы анализа: 384c. $\square$ М.: Высш. шк., 1989. $\square$ Учеб.для химико-технол. спец. вузов.

2. Сапунов, В.А. Термическая деструкция ископаемых углей в присутствии гидроксида калия / В.А. Сапунов, В.А. Кучеренко, В.И. Братчун // Химия твердого топлива. - 1986. - №6. - С. 51-54

3. Кучер Р.В. Структура ископаемых углей и их способность к окислению. /Р.В. Кучер, В. А. Компанец, Л.Ф. Бутузова. - Киев. Наук, дума, 1980. -168c.

4. https://mining-media.ru/ru/article/ekonomic/2469-perspektivy-osvoeniya-ugolnykh-resursov-respublikityva

5. https://ru.wikipedia.org/wiki/

\section{Санчий А.Д. \\ Перспективы использования пармелии в составе фиточая}

Тувинский государственный университет

(Россия, Кьзыьл)

doi:10.18411/spc-22-04-2018-04

idsp: 000001:spc-22-04-2018-04

Правильное питание является одним из важнейших факторов здорового образа жизни, а именно определяет здоровье населения, обеспечивает нормальный рост и развитие человека. А еще содействует профилактике заболеваний, увеличению работоспособности и создает условие для адекватной адаптации людей к окружающей среде. Поэтому особенностью современной пищевой и фармацевтической промышленности является разработка качественно новых продуктов питания, способствующих сохранению и улучшению самочувствия [2].

До настоящего времени лишайники во многом остаются загадкой и считаются интересным объектом для исследования, в силу ряда особенностей их организации и жизнедеятельности. Наряду с лекарственными растениями, лишайники являются широко распространенными долголетними дикорастущими растениями.

Известно использование лишайника «черагы» в народной медицине тувинцев. Так называемые «ивижилер» использовали его в пищу и поэтому не болели почтивсеми тяжелыми болезнями, такими как трахома, бронхит, туберкулез, сахарный диабет и др. До настоящего время они также применяются в народной медицине тувинцев и народов Севера [4].

Самбыла Ч.Н. были проведены изучения особенностей распределения лишайниковых кормовых угодий Тувы, которые применяются под выпас оленя и других видов диких животных, однако литературные сведения об их химическом составе отсутствуют. В связи с тем, что химический состав лишайников, произрастающих на территории Тувы, ранее не изучался и для практического использования его в качестве различных продуктов (биологически активные добавки, 